\title{
ON THE BORDERS OF ETHNOLINGUISTIC EQUIVALENCE: BELARUSIAN-SOUTH SLAVIC PARALLELS
}

\author{
Nikolai Antropov \\ Center for Belarusian Culture, Language and Literature Research \\ National Academy of Sciences, Belarus \\ e-mail: antropov50@gmail.com
}

\begin{abstract}
This article compares and analyses, with the involvement of recent Belarusian materials, the two fragments of Belarusian spiritual culture and relevant South Slavic traditions, related to: a) Christmas (in southern Slawiya, it is concentrated around the badnjak, a log burned on Christmas Eve), and b) bear days/festivities (called kamajedzica in Belarusian ethnoculture). It is acknowledged that the detection of new pairs of Belarusian-South Slavic isolexes/ isodoxes/isopragms or the new interpretation of those detected earlier is not only valuable as a fact, but also as a chance for providing heuristic evaluation of the outcome of such comparison for the purposes of a new comprehension of the nature of different phenomena of spiritual culture under comparison, within their own rite-ritual continua and, in relation to that, for objectifying the historical borders of ethnolinguistic equivalence.
\end{abstract}

Keywords: badnjak, bear days/festivities, Christmas, equivalence, ethnolinguistics, kamajedzica

The particular value of Belarusian-South Slavic ethnolinguistic equivalents (convergences) has been repeatedly pointed out and discussed in scientific literature (Antropov, Cychun, Kryvicki, Radenković, Tolstoi, and others). However, continuing the search in that regard is still relevant, and not only because finding new pairs of isolexes/isodoxes/isopragms or a new interpretation of those already substantiated would be indicative of the existence of ancient bonds between certain language formations in the south and the east of the Slavic world (Cychun 1983: 4), but also because of the possibility to heuristically evaluate the efficiency of such comparison for the purposes of new apprehension of the nature of the phenomena of spiritual culture under comparison, both in their own rites and ritual spheres and in the overall Slavic context in general. The latter lemma seems to be of crucial importance in terms of defining the borders 
of ethnolinguistic equivalence, i.e., posing the question that could be articulated as follows: do the phenomena of the traditional culture of the two Slavic (ethno) linguistic/-cultural continua under comparison have a typological character (with due consideration of deep Indo-European or all-European common roots), or can we assume a multidirectional - both temporal and spatial - genesis of ethnocultural dialectic phenomena of (late)proto-Slavic era?

\section{ETHNOCULTURAL CHRISTMAS COMPLEXES}

In the sense asserted above, it seems not incurious to once again opt for systemic consideration of a number of elements of actional, but especially objectspecific code of such rite complexes that are rich in multi-faceted semantics as Christmas rites and rituals, both in South Slavic and Belarusian traditions. The research earlier conducted by the author on the basis of other material of traditional spiritual culture (Antropov 2004: 75-84; Antropov 2007b: 10-18) has shown that it is the object-specific code that is diagnostic in terms of steady delimitation of homogeneous elements in each one of them. In the South Slavic Christmas traditions, different actions with the Christmas log, the badnjak, seem to be of extreme importance, as is everything related to and happening around it. A general overview of the badnjak as 1) the name of the log that is burnt on Christmas Eve, and 2) the name of the main ritual of the Christmas cycle of the South Slavs has been presented in a number of published works (Kulišić 1970: 20-22; Tolstoi 1995: 127-131) and some local variations and the Common-Slavic perspective of the ritual (in Tolstoi 1986: 128-131). The summarized "benchmark of the ritual", which, in the opinion of Nikita Tolstoi, mainly reflects a Serbian-Bulgarian variation, contains the following set and sequence of ritual activities: felling the badnjak, taking it to the house, putting it up in the yard near the house, bringing it into the house, meeting and greeting the badnjak, laying it on the fire, kissing the badnjak, feeding it, beating the fireplace (this is done by the polaznik, the first person who visits the family on Christmas Day), guarding the badnjak, burning it into two halves, and keeping the soot and ashes for further use in many different ways (cf. Toporov 1976: 9-11 for common features of the ritual).

In the opinion of Tolstoi, some specific motives of South Slavic ritual actions with the badnjak have something in common with the Ukrainian ritual kolodka (chump) ${ }^{1}$ and the Belarusian ritual of bringing firewood into the house for Christmas: ${ }^{2}$ 
V den'Roždestva Christova každyj hozjain, vstavši iz-za stola posle obeda, dolžen vnesti $v$ hatu tri polena drov, kotorye kladutsja na $g r j a d k u$ (matica, poperečnaja perekladina $v$ izbe) $i$ hranjatsja do teh por, poka ne pospeet rož'.

On the day of the birth of Christ, every master of the house, after finishing his lunch, must bring three logs into the house, which should be put on the beam and kept there until the rye has ripened.

It follows from the text that later on these logs are used to heat the barn when the sheaves are about to be dried, with a rare personified, even naive and poetic motivation - so that the barn is protected from fire throughout the whole year. Thus, in addition to the common element of "bringing it into the house", for the Belarusian tradition it is also possible to reconstruct the hidden motif of a wholesome Christmas fire related to Christmas $\operatorname{logs}^{3}$ (cf. a similar appeal in relation to the badnjak). The motif of "bringing the logs into the house" can clearly refer to a similar widespread action that precedes girls' Christmas "oddeven" fortune-telling (e.g. Seržputoŭski 1998 [1930]: 138):

Na peršuju Kuccju. Posle večjery dzeŭki bjaguc' na dryvotnik i bjaruc’ tam ne ličačy vjaliznae bjarjemja droŭ i njasuc' ich u chatu.

At first Kuccia. After supper, the girls run to the woodshed and pick, without counting, a large bunch of firewood and carry them into the house.

The commonality of the object-specific code of the ritual adjoins the abovementioned tradition: the burning of the badnjak / Christmas logs by the master of the house, which in the Belarusian tradition has been recorded in the south of the Sluck (Slutsk) locality of the Minsk Region (Seržputoŭski 1998 [1930]: 141) and in western Polesye (Tolstaya 2005: 84):

a) Na Kaljady zapal'vajuc' agon' $i$ zapal'vac' pavinen mužčyna, a ne žančyna, kab perasceragscisa at pažaru;

At Christmas, a fire is lit and a man should do it, not a woman, to protect himself from the fire;

b) Mužčyny ž rospaljuvaly drova v pyči pjeršogo dnja na Novyj god, na Koljady drugogo dnja i potom na Vodochrišča - try razy.

Men also kindle firewood in the stove on the first day of the New Year, on the second day of Christmas and then on Epiphany - three times.

Without doubt, the "fire-preventive" expansion of the cultural semantics in the Sluck evidence is clearly secondary.

It resembles "feeding the badnjak", which has been mentioned in Tolstaya (1986: 106), i.e., the custom of pouring the remains of the funeral repast (kolivo 
'coliphia'4, perhaps) on the firewood. See a description from eastern Polesye in the same source (ibid.):

Na dedy jak pominajut, iz pominalnogo bljuda $\breve{u}$ bljudečko nemnogo zlivali. A s togo bljudečka na drugij den' vylivajut na drova, šob zgoralo, a dym do boga šoŭ.

When the dead are remembered on Dedy [one of the memorial days of the year], a little is poured into a saucer from a memorial dish. And from that saucer on the second day they pour on wood so that it would burn, and smoke would go to God.

It is clear that time constituents of the actions compared are different (Christmas - Dziady (commemoration of the dead)), but if we take into consideration the existence of the commemorative segment in the overall semantics of Christmas (and Christmastide in general), which has been emphasized repeatedly, the relatedness of these ritual elements will not seem far-fetched.

An interesting parallel to "beating the badnjak/fireplace" by a polaznik (striking the sparks out), which was wishing hosts well, more precisely, the possibility of semantic relatedness of the definitions badnjak/polaznik $\leftrightarrow$ char/ guest, is demonstrated by the following beliefs documented in the Sluck Polesye (Seržputoŭski 1998 [1930]: 160):

a) Kali ŭ pečy drovy raskocjacca tak, što až galaveška ŭpadze da dolu, to z'javicca daljoki gosc';

If in the stove the firewood rolls apart, so that a piece of charcoal even falls down, a distant guest will appear;

b) Kali drovy raskocjacca ŭ pečy tak, što palena abo galaveška vykacicca až na prypek, to hutka prykocjacca gosci.

If the wood rolls apart in the oven, so that a log or a piece of charcoal even rolls out onto the hearth, the guests will quickly roll over.

In the other short text, what is peculiar is a series of verbs with the root $\kappa a u_{-}$ $i u_{-} / \kappa o ́ u_{-}-я u_{-}$- and the prefixes of space semantics, the last of which manifests

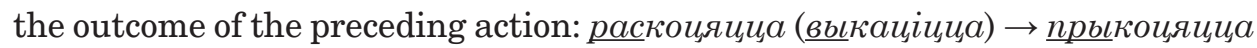
(semantically and derivationally intensified by the preceding $\underline{n p b \iota n e \kappa) . ~}$

However, the most amazing coincidences are marked in the semantics of ritual actions that are related to keeping and reusing badnjak / Christmas soot and ashes, on which, as it is known, the properties of the things that have been burned are projected (Plotnikova 2004a: 666), which, on top of everything else, is once again indicative of the specific status of Christmas firewood in the Belarusian tradition. It is essential that the most important determinative, both in the Belarusian tradition and in South Slavic cultures, is the black colour of 
soot. Thus in Edessa (southern Macedonia) the badnjak char was buried in the vineyard, so that "the grapes would be black", i.e., ripe and juicy; in western Macedonia (Debar) it is kept for treating domestic animals (Tolstoi 1995: 130). Mediated correlations to it can be seen in the opposition of "black soot - black lamb (sheep)", which is present in a number of superstitions written down in the Viciebsk Region: Christmas soot must not be put out because otherwise black sheep will be born; if you rake the fire out from the stove at Christmas and throw it away, black lambs will be born; if you want black sheep to multiply, you should pour Epiphany water over soot and then take it out to the sheepfold (Vasilevich 1998: 354, 362, 379; adapted from Aleksandr Pschelko and Nikolay Nikiforovsky). In the same ethnocultural region, derivatives have also been recorded (that are clearly dependent on basic concepts): lambs will be born black if you dirty your shoes with soot at Christmas; for the sheep not to be bandy-legged, the mistress of the house should leave ashes and soot in the stove at Christmas (Vasilevich 1998: 356, 363; adapted from Nikolay Nikiforovsky and Yevdokim Romanov). The latter belief, which, most probably, could be transformed reconstructively into the Christmas ban on taking soot and ashes out of the house, which also exists in the Bulgarian and Polesye Ukrainian traditions (Plotnikova 2004a: 669-670), is related to the overall semantics of Christmas (Christmastide) evenings being "holy" ones, during which it was undesirable to perform certain actions because of the danger for future crops or domestic animals.

Quite representative is also the ritual use of ashes left after burning the badnjak and firewood at Christmas in the South Slavic and Belarusian traditions (see Tolstoi 1995: 130-131; Plotnikova 2004a: 667-668; Tolstaya 2005: 267; PA; Varlyha 1972: 8; Vasilevich 1998: 334, 371):

1) scattering it in the fields, gardens, and vineyards by the southern Slavs (north-western Serbia (Jadar), Macedonia, Bulgaria (Pirin Region), Viciebsk Region; also observed in Ukraine in Chernihiv (Chernigov) and Zhytomyr oblasts);

2) dusting the roots of planted fruit trees with ashes (in the Bulgarian tradition, wine mixed with ashes and crushed nuts is poured over the roots), so that they bear plenty of fruit (north-western Bulgaria, the area of Kyustendil, Minsk Region (the south of the Sluck District), the central part of western Polesye);

3) sowing grain mixed with ashes (eastern Macedonia, eastern and southern Thrace in Bulgaria, Viciebsk Region $)^{5}$;

4) dusting vegetables and sprouts with ashes against pests (Herzegovina, western Bosnia, Hrodna (Grodno) Region); 
5) rubbing it into the bodies of domestic animals for prophylactic purposes and rubbing it into lichen as an element of remedial magic (Thrace and the area of Plovdiv in Bulgaria, Minsk Region, Homiel (Gomel) Region).

The sacral status of the first Christmas ashes (unique to the Belarusian tradition) is vividly emphasized by its use in Christmas / New Year fortune-telling which predicted the coming back from war (= 'life - death'), recorded in the Viciebsk Region (Volodina):

Byli ne pryšli z armii mužyki, i vos' jany [ženščiny] gadali, ci jos'jany dze žyvyja. Na bljudačak naseili popilu, kab popil byŭ čys'cin'ki, k a l a d n y, vot [kotoryj polučilsja] na pervuju kaljadu, a patom na ftaruju kaljadu možna gadac'. Pos'le nakryvajuc' popil belen'kaj bumažačkaj... patom staviš stakan ... čys'cin'ki, bez rubcoŭ... Vady nalivaiš $i$ kalco [obručalnoje] kidaiš ŭ stakan ... kab jano bylo ... pasradzi stakana... Nu i zerkala, balšoja zerkala. I sadzis'sja, naginais'sja i gljadziš u kalco ŭ zerkali, i vidziš. I vot pagljadzela byla mačacha, $i$ sasedka, $i$ ŭvidzili jany. Adna ŭvidzila bugor zjamli, bugor taki nasypany i palka, i drugaja [to že uvidela].

[After the war] men did not come from the army, and they [the women] wondered if they were alive. The ashes were sprinkled on a saucer, but such that the ashes were clean, from Christmas, [which were left after burning of firewood] on the first day of Christmas, and then on the second day of Christmas you can tell fortune. Then they cover the ashes with white paper... then you put a glass ... clean, without scars [facets]... You pour water and put the ring [engagement] in the glass ..., so that it appears ... in the middle of the glass... And the mirror [you put], a large mirror. And you sit down, lean over, and look at the ring in the mirror, and you see... And then my stepmother and neighbour looked and they saw it. One saw a hillock of soil, a hillock that was piled up, and a stick, and the second [saw the same things].

In view of the above-mentioned practices, both the issues concerning the obvious ethnocultural Belarusian-South Slavic equivalents in the field of Christmas ritualism, which, without any doubt, are difficult to be reduced to their typological essence, and the potential linguistic and, hence, ethnolinguistic indices of this equivalence have acquired a new dimension. This is all the more essential, as the existence of the terminological row in the ritual and rite field, in particular, the names of the rite on the whole, its important parts, etc., facilitate its conservation to a large extent and - when one or another rite-ritual ceases to be practiced - also the memories thereof (which will be displayed later through another example). As for the badnjak, such an attempt was made by 
Vladimir Toporov, who believed that when "taking into account the importance of ashes in this rite..., we must consider the possibility of including in a specified range of words of the Russian and Belarusian budnik, budnyi (compare budnoje delo) 'zolnik, -yi', 'potashnik, -yi'” (Toporov 1976: 10). However, to the best of our knowledge, this remark has never evolved into anything bigger, perhaps because the Russian and Belarusian names are derivatives of the borrowing from the Polish language (in Belarusian literary texts since 1527, in Ukrainian texts since 1530, in Russian texts since 1634): buda "forestry enterprise for wood processing; tar distillatory", "tar distillation, potassic, or saltpetrous enterprise in the forest and a settlement near it", "forest products" (e.g., chotyri budy popelu dobrogo) (ESBM 1978: 398-399; ESUM 1982: 277; GSBM 1982: 231; Shelud'ko 1931: 23; SRJ 1975: 344, 346).

Consequently, it should be acknowledged that on the Belarusian (and East Slavic on the whole) linguistic territory, there are simply no special cultural terms that could be correlated with proto-Slavic dialectal ones (South Slavic *bzdbnz (SP 1974: 459) or *bsdbńbjb (ERSJ 2003: 69). However, it is perfectly clear because even the South Slavic badnjak, as was aptly noted by Nikita Tolstoi, "is neither typologically nor genetically a single whole. It contains different aspects, some of which could be qualified as Slavic and Baltic-Slavic (opening up to the Indo-European perspective) and others as Balkan ones (opening up to the same perspective), and the third group can be qualified as the outcome of various impacts and effects in wide areas of ethnocultural tradition" (Tolstoi 1986: 131; see more information about the latter in Kulišić 1970: 22).

The material presented in this text allows us to make an assumption concerning the fact that the existence of a consistent row of correlative elements of actional, object-specific, subject-specific, and other codes in Belarusian and South Slavic Christmas traditions is, in terms of the Belarusian traditional culture, not so much a typological, but rather a genetic factor, determined by the peculiarities of the ethnogenesis of the Belarusians. The names and the aspects of cultural terminology as such are represented here by the opposition of existence/absence, but with the availability of nominative rows, with their own lexical database in each of the traditions (Antropov 2007a: 71), which could be one of the themes of ethnolinguistic equivalence of this kind.

\section{BEAR DAYS/FESTIVITIES}

Another type of ethnolinguistic equivalence is revealed in the extremely archaic South Slavic bear days/festivities and relevant local Belarusian traditions in two ethnocultural areas that are geographically opposite. Notably, in this case, 
there is a reverse situation in the terminological field, namely, the availability of the name of the rite and, at the same time, of the ritual term in the Belarusian tradition, with the absence of such in the South Slavic and the neighbouring Albanian traditions. It should be emphasized that it is only in the Belarusian, on one side, and in the Macedonian, Serbian and, partly, Albanian (Plotnikova 2004b: 292-293) ethnocultures, on the other side, that these rituals have been preserved in quite an integral whole, as compared to individual representations and actions in other Slavic traditions, which are fragments of the European or even the Eurasian cultural heritage of the extremely distant past (see Ivanov \& Toporov 1994: 128-130; Gura 1997: 211-215 for additional information). This refers to the Belarusian kamajedzica and the New Year customs of the ritual feeding of a bear (a she-bear) observed in Macedonia (in the neighbourhood of Skopje, Tetovo), Serbia (in Kosovo, the Resava region), and southern Albania among the Orthodox inhabitants of the Deval River (Schneeweis 1925: 83; 1961: 109; Plotnikova 2004b: 292).

The Macedonians and the Serbians from Kosovo cook a thick parturient porridge for a she-bear who will supposedly give birth on New Year's Eve (St. Vasily's (Basil's) Day) (Serb. коте се мечка), мечкина повојница оr бареница, mainly from corn flour: "Свака кућа прави колобоћне баренице за повојницу" (In each house a special barenica is cooked as a gift [for the bear]) (Debelković 1907: 251), which is sometimes mixed with milk but is still quite thick (Elezović 1932: 32; 1935: 13). It is revealing that just about all of the Serbian names for bread/flatbread (of the meals of the mămăligă ${ }^{6}$ type) with the roots баран-, боран-, барен- are the names of ceremonial dishes and are directly or indirectly related to the naming of domestic animals (see ERSJ 2003: 187). The Serbs of the Resava River baked a special kind of bread called мечки повојница (a gift to a new-born bear). Compare with the similar barenicu kačamak or nešto za ručak (gift to a bear) in Kosovo, which was brought out of the house by the mistresses of the house who were addressing the bear: "Evo ti nosimo povojnica, posle da ni ne diraš stoka" (This is our gift that we bring you, so that you do not tear [ruin] our cattle) (Vukanović 1986: 373). The Orthodox inhabitants of southern Albania baked a special round loaf (a pie or flatbread) called arushkë (a she-bear). ${ }^{7}$ It is important to stress that before eating the arushkë, it was taken out of the house for several minutes (Ivanova 1973: 299-307). It was the idea of Anna Plotnikova that in the general semantics of the rite, both the actions aimed at mollifying the bear and protective, apotropaic acts are combined, and are related to a symbolic "putting out" of the bear's eyes (which is imitatively done by pinning of the upper bread crust or piercing the bumps on it), so that in summer the bear would not destroy corn plantings or attack cattle (Plotnikova 2004b: 292-293). 
As for the Belarusian kamajedzica, until recently, it was seen as something ethnoculturally unique, since researchers could only use a single record of the rite, which was described and published in the last quarter of the nineteenth century by the local priest Simeon Nečajev in the then existing Biahomí Parish of the Barysaŭ District of the Minsk Governorate (Nečajev 1874: 229-230). This description was noticed by a famous collector and publisher of Belarusian folklore, Pavel Shein, and was included in the third volume of his renowned collection (Shein 1902: 162-163), after which it was repeatedly published in many different publications. Comparatively recently, the author of this article discovered a similar, anonymous text with a number of important additions, which was published in 1879 in an eparchial yearbook. Judging by some common aspects of both publications, this text had been written by Nečajev. It is republished for the first time below (it has Latin characters based on the contemporary Cyrillic alphabet; the author's spelling has been more or less preserved, while punctuation marks have been preserved completely; angle brackets contain the reconstruction of the fragments of the text which were clearly typographical mishaps in the original text):

Kamojedica prazdnuetsja v čest' medvedja, i ustanovlena dlja togo, čtoby on ne sjel kogo-libo, kogda budut' hodit' letom v les za lykami, jagodami, gribami i orechami. Počemu v označennyj den' oni ničego ne delajut, dlja togo, čtoby i medved' ničego ne sdelal chudogo. Ženščiny, obyknovenno $v$ etot den' odna druguju straščajut tak: 'oj ne prad<i> segodnja, kuma, bo medved'zadjarec', jak pojdeš u <les pa> gribe'-Meždu tem prigotovljajetsja obed, sostojaščij iz sledujuščich kushan'jev: varenoj botvy ot repy, ili brjukvy, zasušennych letom, - takoe bljudo prigotovljajetsja dlja togo, čtoby napomnit', čto i medved' možet pitatsja rastitelnoju piščeju, - i vtoroe bljudo kamy, ot kotorogo i prazdnik poluča<e>t nazvanije kamajedicy. Kamy sii delajutsja iz parennogo gorocha, $i$ vsja sem'ja naedajetsja sim bljudom nepremenno dosyta. Posle obeda vse ložatsja spat', no sobstvenno ne spjat, a pominutno povoračivajas's boka na bok, revut $i$ mychat pomedvežjemu, čtoby napomnit' etim rev i mychanie medvedja, ležaščego $v$ berloge. Nakonec, vse vstajut i raschodjatsja; znachit i medved' vstal iz svoej berlogi i pošel po lesu. Po mneniju krest'jan, medved' na Blagoveščenie probuždajetsja ot spjački, vot potomu $i$ svoju kamoedicu oni prazdnujut pred etim dnem, čtoby črez to vstretit' medvedja s blagopoželanijami. Prazdnik etot osobenno sobljudajetsja krest'janami derevni Volči, kotoraja okružena byla dremučimi i neprochodimymi lesami, v kotorych vodilos' množestvo medvedej, pričinjavšich mnogo vreda, istrebljaja celyje polja, osobenno gorocha, a takže často ubivavšich skot i ljudej, a inogda jakoby vyryvavšich i pokojnikov iz mogil. Vot, čtoby umilostivit’ sego zverja, ljudi $i$ 
pridumali v čest' ego prazdnik, kotoryj, bez vsjakogo somnenija, vedet svoje načalo ot vremen jazyčestva, $i$ daže imejetsja predanije, čto $v$ starinu v etoj mestnosti ljudi bogotvorili medvedja. Nekotorye kamojedicu spravljajut $v$ sredu na četvertoj nedele velikogo posta.

Kamojedzica is celebrated in honour of the bear, and is set so that it does not eat anyone when they go to the forest in the summer for splint [fibrous part under the bark of deciduous trees], berries, mushrooms and nuts. Therefore, on this day they do nothing, so that the bear does nothing wrong. On this day, women usually frighten each other in the following way: 'Oh, do not strand today, kuma, because the bear will kill you when you go to the forest for mushrooms.' - Meanwhile, a dinner is cooked, consisting of the following dishes: boiled leaves from turnips, or swede dried in summer - such a dish is cooked in order to remind that the bear can also eat vegetarian food - and the second dish is kamy, from which the feast received its name kamajedzicy. This kamy is made from steamed peas, and the whole family eats this dish to the full. After lunch, everyone goes to bed, but they do not actually sleep, but are constantly turning from side to side, roaring and mumbling like a bear, to remind the roar and mooing of a bear lying in a lair. Finally, everyone gets up and leaves; then the bear also rose from his lair and walked through the forest. According to the peasants, on the Annunciation the bear is awakened from hibernation, that is why they celebrate their kamojedzica before this day, in order to meet the bear with good wishes. This holiday is especially observed by the peasants of the village of Volčy, which was surrounded by dense and impenetrable forests, in which there were many bears that caused much harm, destroying whole fields, especially peas, and also often killed livestock and people, and sometimes allegedly tore dead people from the graves. Here, in order to propitiate this beast, people invented a feast in its honour, which, without any doubt, originates from the time of paganism, and there is even a tradition that in olden times people worshiped a bear in this locality. Some people mark kamojedzica on Wednesday in the fourth week of the Great Lent.

As is seen from this verbose text, relevant elements in bear-related rituals within the traditions that are being compared overlap in the most prominent features, namely in the culinary code (cornmeal porridge - pea balls), the motifs of making nice and greeting the animal, which can serve as evidence of their originally totemic nature (see a direct reference in the text: "in the olden times, people were worshipping bears here"; see also Licjvinka 2001: 61). This text is also very important because it virtually eliminates the issue concerning 
the authenticity of the record of kamajedzicy. (Admittedly, the South Slavic material has propagated this authenticity even earlier.) However, some of the issues might still be under consideration, and, firstly, it concerns the name, since the composite word колоедица (kamajedzicy) with an absolutely transparent structure (eating komy from boiled peas) cannot but seem artificial to some extent, but more precisely as an outcome of folk etymology and/or terminological creation by the people having participated in the rite. However, an attempt to link the Belarusian naming to the name of the ancient Greek bear festival Comoedia in honour of the goddess Artemis, which was supposedly celebrated around the 25th of March (Zajkoŭski \& Sanjko 2004: 334), should be regarded as ill-founded. No matter how original it might seem, it has never been supported with any kind of historical or ethnocultural evidence: fundamental sources related to the ancient Greek language and culture do not confirm the existence of such a festival.

In recent years, Belarusian folklorists have filed some new records directly concerning the rite or related to it, which expressly contain the naming, for example:

a) Ot jak Kamaedzica. Gavorac': na Kamaedzicu!... Ja čula i znaju, što takoe slova jo: Kamaedzica. A što za Kamaedzica? što-to takoe Kamaedzica... 'Na Kamaedzicu,' - kazhuc'! (Boganeva \& Varfolomejeva) Here's how Kamaedzica. They say: on Kamaedzica!... I heard and I know that there is such a word: Kamaedzica. And what kind of Kamaedzica? What is Kamaedzica... 'On Kamaedzica,' they say!

b) Колэдь, Колоедьца. Колоедьца, вона ж всю жьзнь вэдэица, кілько cвim йісьия. (Boganeva \& Volodina)

Komedy, Komojedyca. Komojedyca, it has always been [there], as long as the world is there.

It should be pointed out that the other record (see the information about its contents below) takes the bear rite-ritual practices outside of the borders of the south of the Viciebsk Region.

While there is no specific term, certain motifs (a special day for greeting the bear; a ritual action motivated by rendering assistance to the bear who is waking up from its winter sleep) are also present in the legend about the reincarnation of a man who wanted to scare God, into a bear, which was recorded comparatively close to the Biahoml area of the existence of the rite (Viliejka District of the Minsk Region): 
... u tym carstve ǔžo gjetkae s'vjata adzin dzen': pa zjamli kačajucca. Gjeta vedz'mjadzju pamagajuc'... [u] toj dzen', [u] katory vjadz'medz' nastrašyŭ Boga. (Boganeva \& Volodina)

... in that kingdom there is such a holiday on one day: they are rolling on the ground. It helps the bear ... on that day in which the bear frightened God.

Thus, there are reasons to claim that relevant practices related to bear days spread in Belarus much more widely than it had been believed before.

As for the ritual semantics of the Belarusian kamajedzicy, comparatively recent records from the Motal ethnocultural area of western Polesye (Psyščava, Ivanava District, Brest Region), which are directly correlated with the evidence found in the territories where the South Slavs / Balkan people lived, considerably expand the understanding of it and, most importantly, allow issues of more general character to be discussed. Stratification analysis of the record made in Psyščava allows the following scheme with respect to individual codes to be built:

- Temporal: St. Thomas Week (after Easter):

... buly takjee dni $v$ aprjeli misjacy. Na provody zymy ... Eto pos'lja Vjelykonnja Provodnaja nydilja nazyvajecca ... Zimu progonjaty, myd'vidja kormity... V etu nydilju progonijut' zymu. I ot vsjo gjeto robymo.

... there were such days in April. During the farewell of the winter... This is after Easter; it's called the farewell week... We drive out the winter and feed the bear... This week, they drive out the winter. And all this is done.

- Spatial: the backyard where people put food and drinks:

To i prychodyv [medved'] ... užje vin idje v silo, kob dje čym požyvytysja... [Korzinu s ugoščeniem stavili] na dvori. U chatu ž myd'vid' nje prydje. And so [the bear] came... already going to the village to get some food somewhere [the basket was set with a treat] in the yard. The bear does not come into the house.

- Culinary: wheat kliocki (dumplings), honey, kissel:

Vo gety galušky, vo gety komy... Tisto rosčynjajecca na droščjech, zamjesyty vrano, tak gustjen'ko nakačetje etych buločok maljen'kih, i vkydaju v vodu, a oni povsplivajut', takie puchkjen'ki... I takie vo kamy nazyvalysja... Tisto $v$ vodi varycca, to ž nazyvalosja galušky, i komy zvaly ich ... jogo $\check{z}$ [medvedja] trjeba ... nakormyty vsim tym: $i$ komamy, i mjedom, vsim kisjeljom. Here are these galušky, here are these komy ... The dough is prepared and raised, you should [knead] it early [in the morning], you'll make more small buns; and throw them into the water, and they float up, so fluffy ... And so these were called kamy... The dough is boiled, and it was called 
galušky, and komy also... it [the bear] must be fed with all this: komy, and honey, and kissel of course.

- Object-specific: a special basket:

Nu naklaly ž myd'vidjovy v kiš, da njechaj užje jist'.

They put it for the bear in the kosh [basket], and let him eat.

- Motivational:

a) greeting the bear as "the king of the forest":

Vin žje ž car lisu. Do jogo ž trjeba pryladytys', jogo ž trjeba šanovaty, odobraty, nakormyty...

He is the king of the forest. You should learn to deal with him, it is necessary to respect him, to collect [food], to feed him...

b) mollifying the bear as a precaution:

Šo kormyly mid'vidja, kob nje robyv porčy ljudjam... Tody ž [posle togo, kak ugostitsja] vin idje i nikomu porčy nje robyt'.

They fed the bear, so that he did not damage people... Then [after the treats] he goes and does not damage anyone.

Certainly, this invariant of ritual actions is a far cry from the "classical", Biahomí scenario, but instead it resembles the Macedonian, Serbian, and Albanian scenarios described above, which allows us to notice another Belarusian (Polesyan)South Slavic isodox of the bear day/festivity. It is also essential to point out obvious inconsistencies, the most important of which is related to the timing parameter. However, we should bear in mind the correlative ritual importance of New Year's Eve (Christmas Eve) in particular (and St. Vasily's (Basil's) Day at the same time), on the one hand, and St. Thomas Week (Farewell Week), on the other hand (we should also think about Biahoml's Eve of the Annunciation Day and Mid-Pentecost). All of these time periods actualize the basic temporal opposition of the beginning/end and optionally the beginning/middle/end.

The relation between the temporal code and the motivations behind certain "actions"/"behaviour" of certain actions ascribed to the object, i.e., to a bear (a she-bear) in both ethnocultural areas is of particular interest. Indeed, in the Balkan tradition, the New Year and New Year's Eve are related to birth (the new appearance of a bear cub); in the Belarusian tradition the Eve of Annunciation Day and Mid-Pentecost is the time related to the waking up of the bear after winter sleep as the new beginning of vital activity (Biahoml area), and St. Thomas Week is for the greeting of the bear and giving it treats, which in the Motal area is perceived as saying farewell (tody ž vin idje (then he goes)). It should definitely be pointed out that all of those three motifs are unique transformations of the overcoming of different kinds of the transition situation by the object (perhaps once being a totem). 
The comparison of the South Slavic/Balkan material with the new (western Polesyan) records, kamajedzicy also allows a question to be raised concerning the availability in the Belarusian ethnoculture of two interrelated parts of one single ritual of a bear day/festivity with its own ritual practices, one of which, namely the imitative one, was cultivated in the southern Paazerje in Belarus, while the second one, which generalizes the motifs of greeting and saying farewell, was practiced in central Zaharoddzje (western Polesye). It is worth mentioning that the first part is not represented in some ethnocultural areas of Slawiya even at the level of individual echoes, perhaps with the exception of ritual bear disguises and the existence of the pea ingredient in the culinary code, for example, during the bear days that take place on Saint Andrew's Day (30 November/13 December) (see Vinogradova \& Tolstaya 1995: 109-111 for additional information).

\section{CONCLUSION}

The material represented in the research, which manifests the ethnolinguistic equivalence based on South Slavic and Belarusian correlations at Christmas time and on bear days/festivities allows the historical borders of such equivalence to be objectified. In the first case, the entire set of correlations analysed, which are of clearly consistent nature, provides evidence of their common (late) proto-Slavic foundation and further genesis in the Slavic space of traditional spiritual culture. The comparison of South Slavic bear days/festivities and the Belarusian correlations suggest that in this case we are dealing with the phenomena of typological essence, since both for South Slawiya and for the Belarusian part of the eastern Slavic ethnocultural continuum, the different ways of worshipping the bear are the Indo-European (common European) heritage.

\section{ACKNOWLEDGEMENTS}

The article was written as part of a project financed by the Foreign Ministry of Estonia through the Developmental Cooperation Programme (66-2015-A). 


\section{NOTES}

1 It is very important to point out here that the ritual actions with a chump are also native for Belarusian traditional culture (see Antropov 1998: 21-33 for additional information).

${ }^{2}$ In the article (Tolstoi 1995) the evidence refers to north-western Belarus. However, its primary source is an anonymous ethnographic note from a geographically opposite region, namely from the Mahilioŭ (Mogilev) Governorate (see Sueveriya 1849: 100).

3 A distant but related parallel to the above-mentioned tradition is planting a birch log under the threshold of a new stable, which is also described in the same source as a peculiar fertility stimulator - "so that there would be plenty of horses" (Sueveriya 1849: 117).

4 Boiled rice with raisins and honey.

5 At this point, it should be brought to notice that on the basis of the analysis of the actions listed above, a fundamentally different motivational essence of the ritual Christmas log burning could be reconstructed, which actualizes the opposition of fertility/infertility: "Supposedly, burning wood in the fireplace partially acquired the function of purification. ... A fruitless tree that had been purified with fire became fructiferous" (Strakhov 2003: 162). In this context, curious is the evidence of the first heating of the new house (also with the purpose of preventing fire), which can be found in the record from the historical Mahilioŭ Region about heating up drying-houses with Christmas firewood - namely apple tree firewood (Sueveriya 1849: 100).

6 Thick porridge of coarse maize meal.

7 Interestingly, the same realia was observed in the southern German ethnocultural area: in Lüneburg (Lower Saxony), special breads in the shape of a bear were baked for Christmas, which were afterwards given away as gifts to wish the receiver success in the new year (Makovsky 1996: 215).

\section{MANUSCRIPT SOURCES}

Boganeva \& Varfolomejeva = Boganeva, Elena \& Varfolomejeva, Tamara. Ličnyje arhivy . [Personal Archives.]

Boganeva \& Volodina = Boganeva, Elena \& Volodina, Tatiana. Ličnyje arhivy. [Personal Archives.]

Volodina = Volodina, Tatiana. Ličnyj arkhiv. [Personal Archive.] 


\section{REFERENCES}

Antropov, Nikolai 1998. Belorusskie etnolingvisticheskie etiudy: 1. koloda/kolodka. [Belarusian Ethnolinguistic Studies: 1. koloda / kolodka.] In: T. Agapkina \& A. Zhuravlev \& S. Tolstaia (eds.) Slovo i kul'tura: Pamiati Nikity Il'icha Tolstogo. Vol. 2. Moscow: Indrik, pp. 21-33. Available at http://inslav.ru/publication/slovo-ikultura-pamyati-nikity-ilicha-tolstogo-m-1998-t-i-ii, last accessed on 18 May 2018. Antropov, Nikolai 2004. Ab etnalingvistychnaj ekvivalentnasci ŭ slavyanskih nekantaktuyuchyh arealah (belaruska-slavacki aspekt). [On Ethnolinguistic Equivalence in Slavonic Noncontact Areas (Belarusian-Slovak Aspect).] In: N. Kiseleva (ed.) O spoločných hodnotách v slovensko-bieloruských vztahoch: Zborník materiálov $z$ vedeckej konferencie Slovensko-bieloruské vztahy. Banska Bystrica: Poniky, pp. $75-84$.

Antropov, Nikolai 2007a. Kaštoŭnasnyja aryjenciry bielaruska-inšaslavianskaha etnalinhvistyčnaha paraŭnannia. [Value Orientations of the Belarusian-OtherSlavonic Ethnolinguistic Comparison.] Bielaruskaja linhvistyka [Belarusian Linguistics], Vol. 60, pp. 64-76.

Antropov, Nikolai 2007b. Traditsionnaia kartina mira v belorussko-bolgarskoi etnolingvisticheskoi prizme. [Traditional Worldview in the Belarusian-Bulgarian Ethnolinguistic Prism.] In: B. Norman \& N. Suprunchuka (eds.) Iuzhnoslavianskie iazyki $v$ ikh istorii i sovremennom sostoianii. [South-Slavic Languages in their History and Current State.] Minsk: Izd. I. P. Logvinov, pp. 10-18. Available at https://uploads.philology.by/ms/suprunchuk2007serb_gram_interact.pdf, last accessed on 18 May 2018.

Cychun, Genadz 1983. Paŭdnjovaslavjanska-ŭshodneslavjanskija moŭnyja suvjazi: Da prablemy slavjanskaga ŭkladu ŭ balkanski moŭny sajuz. [South-Slavic East-Slavic Linguistic Ties: On the Issue of Slavonic Contribution to the Balkan Language Area.] IX Mizhnarodny z'ezd slavistaŭ: Daklady. [9th International Assembly of Slavonic Scholars: Papers.] Minsk: Navuka i technika.

Debelković, Dena 1907. Običaji srpskog naroda na Kosovu Polu. [The Customs of the Serbian People in the Kosovo Field.] Srpski etnografski zbornik [Serbian Ethnography Collection], Vol. 7, pp. 171-332.

Elezović, Gliša 1932. Rečnik kosovsko-metohiskog dijalekta. [Dictionary of the KosovoMetohija Dialect.] Vol. I. Belgrade: Srpska kraljevska akademija.

Elezović, Gliša 1935. Rečnik kosovsko-metohiskog dijalekta. [Dictionary of the KosovoMetohija Dialect.] Vol. II. Belgrade: Srpska kraljevska akademija.

ERSJ 2003 = Etimološki rječnik srpskog jezika . [Etymological Dictionary of the Serbian Language.] Vol. 1. Belgrade: Institut za srpski iezik.

ESBM 1978 = Etymalagičny sloŭnik belaruskaj movy. [Etymological Dictionary of the Belarusian Language.] Vol. 1. Minsk: Navuka i technika / Belarus. navuka.

ESUM 1982 = Etymologičnyj slounyk ukrajins'koji movy. [Etymological Dictionary of the Ukrainian Language.] Vol. 1. Kyiv: Naukova dumka.

GSBM 1982 = Gistaryčny sloŭnik belaruskaj movy. [Historical Dictionary of the Belarusian Language.] Vol. 1. Minsk: Navuka i technika.

Gura, Alexandr 1997. Medved'. [The Bear.] In: N. Tolstoi (ed.) Slavjanskie drevnosti: Etnolingvističeskij slovar'. [Slavic Antiquities. Ethnolinguistic Dictionary.] Vol. 3, Moscow: Mezhdunarodnyje otnoshenija, pp. 211-215. 
Ivanov, Vyacheslav \& Toporov, Vladimir 1994. Medved'. [The Bear.] In: S. Tokarev (ed.) Mify narodov mira. [Myths of the World.] Vol. 2, pp. 650-651. Moscow: Sovetskaia Entsiklopediia. Available at https://www.indostan.ru/biblioteka/ knigi/2730/3412_1_o.pdf, last accessed on 18 May 2018.

Ivanova, Julia 1973. Albancy. [The Albanians.] In: S. Tokarev (ed.) Kalendarnye obychai i obriady v stranakh zarubezhnoi Evropy XIX - nachalo XX v.: Zimnie prazdniki. [Calendar Customs and Rites in European Countries outside Russia in the 19thEarly 20th Centuries: Winter Holidays.] Moscow: Nauka, pp. 299-307.

Kulišić, Špiro 1970. Badnjak. [Christmas Log.] In: Špiro Kulišić \& Petar Ž. Petrović \& Nikola Pantelić (comps.) Srpski mitološki rjecnik. [Serbian Mythology Dictionary.] Belgrade: Izdavachko preduzeћe Nolit, pp. 20-22. Available at https://www. scribd.com/doc/204003750/Srpski-Mitoloski-Recnik-Grupa-Autora, last accessed on 21 May 2018.

Licjvinka, Vasil 2001. Svjaty i abrady belarusaŭ. [Holidays and Rites of the Belarusians.] Minsk: Belarus.

Makovsky, Mark 1996. Sravnitel'nyi slovar' mifologicheskoi simvoliki v indoevropeiskikh iazykakh: Obraz mira i miry obrazov. [Comparative Dictionary of Mythology Symbols in Indo-European Languages: Worldview and Worlds of Views.] Moscow: Gumanit. izd. tsentr Vlados.

Nečajev, Simeon 1874. Prazdnik komoedicy. [The Holiday of Kamajedzica.] Minskie eparkhial'nye vedomosti [Minsk Diocesan News], Vol. 7, pp. 229-230.

PA = Polesskij arhiv Instituta slavjanovedenija Rossijskoj Akademii nauk. [Polesye Archive of the Institute of Slavic Studies of the Russian Academy of Sciences.]

Plotnikova, Anna 2004a. Pepel. [Ashes.] In: N. Tolstoi (ed.) Slavianskie drevnosti: Etnolingvisticheskii slovar'. [Slavic Antiquities: Ethnolinguistic Dictionary.] Vol. 3. Moscow: Mezhdunarodnyje otnoshenija, pp. 666-670.

Plotnikova, Anna 2004b. Etnolingvisticheskaia geografiia Iuzhnoi Slavii. [Ethnolinguistic Geography of the Southern Slawiya.] Moscow: Izd-vo Indrik.

Schneeweis, Edmund 1925. Die Weihnachtsbräuche der Serbokroaten. Vienna: Verlag des Vereines für Volkskunde.

Schneeweis, Edmund 1961. Serbokroatische Volkskunde: Volksglaube und Volksbrauch. Erster Teil. Berlin: De Gruyter.

Seržputoŭski, Aljaksandr 1998 [1930]. Prymhi i zababony belarusaŭ-paleshukoŭ. [Superstitions and Prejudices of the Polesye Belarusians.] Minsk: Universiteckaje.

Shein, Pavel 1902. Materialy dlia izucheniia byta i iazyka russkogo naseleniia SeveroZapadnogo kraia. [Materials to Study the Lives and Language of the Russian Population of the North-Western Land.] Vol. 3. St. Petersburg: Tip. Imp. AN. Available at http://books.e-heritage.ru/book/10084991, last accessed on 21 May 2018.

Shelud'ko, Dmytro 1931. Nimec'ki elementy v ukrajins'kij movi. [German Elements in the Ukrainian Language.] Zbirnyk komisiji dlja doslidžennja istoriji ukrajins’koji movy. [Collection of the Commission on the Studies of the History of the Ukrainian Language.] Vol. 1. Kyiv.

SP 1974 = Stownik prastowiański. [Common Slavic Dictionary.] Vol. 1. Wrocław: Ossolineum. 
SRJ 1975 = Slovar' russkogo jazyka XI-XVII vv. [Dictionary of the Russian Language of the 11th-17th Centuries.] Vol. 1. Moscow: Nauka. Available at http://etymolog. ruslang.ru/doc/xi-xvii_1.pdf, last accessed on 21 May 2018.

Strakhov, Alexandr 2003. Noch' pered Rozhdestvom: Narodnoe khristianstvo i rozhdestvenskaia obriadnost' na Zapade i u slavian. [Christmas Eve: Folk Christianity and Christmas Rituals in the West and in Slavic Cultures.] Palaeoslavica, Vol. 11, Supplementum I.

Sueveriya 1849 = Sueveriia i predrassudki v Mogilevskoi gubernii. [Superstitions and Prejudices in the Mahilioŭ Governorate.] Mogilevskie gubernskie vedomosti [Mahilioŭ Governorate News], No. 6, pp. 99-100; No. 7, pp. 117-118; No. 8, pp. 138-140.

Tolstaya, Svetlana 1986. Polesskii narodnyi kalendar': Materialy k etnodialektnomu slovariu. [Polesye Folk Calendar: Material for the Ethnic Dialect Dictionary.] In: L. E. Kalnyn' \& T. N. Moloshnaia (eds.) Slavianskoe i balkanskoe iazykoznanie. Problemy dialektologii: Kategoriia posessivnosti. [Slavonic and Balkan Linguistics Problems of Dialectology.] Vol. 10: D-I. Moscow: Nauka, pp. 98-131.

Tolstaya, Svetlana 2005. Polesskii narodnyi kalendar'. [Polesye Folk Calendar.] Moscow: Indrik. Available at http://inslav.ru/publication/tolstaya-s-m-polesskiy-narodnyykalendar-m-2005, last accessed on 21 May 2018.

Tolstoi, Nikita 1986. Balkano-slavianskii badniak v obshcheslavianskoi perspektive. [The Balkan-Slavic Badnjak in the Common Slavic Perspective.] In: V. Ivanov \& V. Neroznak \& V. Toporov \& T. Tsiv'ian (eds.) Balkany $v$ kontekste Sredizemnomor'ia:Problemy rekonstruktsii iazyka i kul'tury. Tezisy i predvaritel'nye materialy $k$ simpoziumu. [Balkans in the Context of the Mediterranean Region: Problems of the Reconstruction of Language and Culture.] Moscow: Nauka, pp. 128-131.

Tolstoi, Nikita 1995. Badnjak. [Christmas Log.] In: N. Tolstoi (ed.) Slavianskie dreunosti: Etnolingvisticheskii slovar'. [Slavic Antiquities: Ethnolinguistic Dictionary.] Vol. 1. Moscow: Mezhdunarodnyje otnoshenija, pp. 127-131.

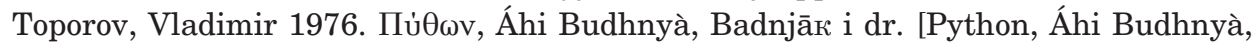
Badnjak, and Others.] In: O. N. Trubačev (ed.) Etimologija 1974. [Etymology 1974.] Moscow: Nauka, pp. 3-15.

Varlyha, Adam 1972. Zababony. [Superstitions.] New York: Zaranka.

Vasilevich, Uladzimir 1998. Žyccja advečny lad: Belaruskija narodnyja prykmety i paverï. [The Eternal Way of Life: Belarusian Folk Signs and Beliefs.] Vol. 2. Minsk: Belarus.

Vinogradova, Liudmila \& Tolstaya, Svetlana 1995. Andrej. N. Tolstoi (ed.) Slavianskie drevnosti: Etnolingvisticheskii slovar'. [Slavic Antiquities: Ethnolinguistic Dictionary.] Vol. 1. Moscow: Mezhdunarodnyje otnoshenija, pp. 109-111.

Vukanović, Tatomir P. 1986. Srbi na Kosovu. [The Serbs in Kosovo.] Vol. 2. Vranje: Nova Jugoslavija.

Zajkoŭski, Edvard \& Sanjko, Sjarhej 2004. Mjadz'vedz'. [The Bear.] In: S. Sanjko (ed.) Belaruskaja mifalogija: Encyklapedyčny davednik. [Belarusian Mythology: Encyclopaedic Reference.] Minsk: Belarus, pp. 333-336. 